\title{
KEBEN (BARRINGTONIA ASIATICA), MOTIF DAN PEWARNA BATIK
}

Djandjang Purwo Sedjati ${ }^{1}$ (mrs.djandjang@gmail.com), Fakultas seni Rupa Institut Seni Indonesia Yogyakarta)

\begin{abstract}
ABSTRAK
Perkembangan batik di Yogyakarta cukup menggembirakan, namun bila melihat batik khas Yogyakarta di pasaran masih di dominasi motif lama yang sudah ada sejak dulu. Motif baru khas Yogyakarta belum nampak secara signifikan, kalau pun ada masih sebatas mengkomposisikan tata letak beberapa motif yang dijadikan satu dalam sebuah kain. Hal ini kurang menjadi daya tarik, sehingga diperlukan karya ciptaan baru yang kreatif dan inovatif yang akan memperkaya motif batik khas Yogyakarta dan akan memantabkan kedudukan sebagai kota batik dunia. Berangkat dari kondisi tersebut, penulis ingin menciptakan motif baru dengan mengambil tumbuhan Keben (Barringtonia Asiatica) sebagai motif dan pewarna alam pada kain panjang batik tulis. Metode pustaka dan metode observasi digunakan untuk mengumpulkan data. Metode Practiced Based Research digunakan untuk memperoleh pengetahuan baru melalui riset praktek dan hasil riset praktek. Metode Penciptaan Seni Kriya Pola Tiga Tahap Enam Langkah digunakan untuk menggali sumber ide dan perancangan. Metode Eksperimen dan Improvisasi juga digunakan penulis untuk mendapatkan pengetahuan baru dari eksperimen yang dilakukan terutama pada pewarna alam serta improvisasi bila dalam pelaksanaan menemukan ide-ide baru. Karya yang dihasilkan berupa 4 lembar kain panjang batik tulis sutera motif stilisasi daun,bunga dan buah Keben dengan zat warna alam Keben dikombinasikan pewarna alam lain yang menghasilkan warna khas batik Yogyakarta. Pola yang dipakai adalah pola Ceplok, Parang, dan Lung-Lungan.
\end{abstract}

Kata Kunci : Keben, Batik, Warna Alam

\section{PENDAHULUAN}

Alam dan unsur-unsurnya menjadi sumber penciptaan dan inspirasi suatu karya seni yang tak terbatas. Salah satu karya budaya bangsa yang adiluhung yang banyak menggunakan unsur flora atau tumbuhan dan sarat dengan makna simbolik adalah budaya batik yang dalam penggambarannya tidak digambar secara natural seperti apa adanya, tetapi sudah distilisasi atau digubah sesuai dengan maksud dan kebutuhannya. Alam ini kadang-kadang dipandang sebagai tema, kadang-kadang sebagai motif. (Soedarso, 1990 : 33).

Bila melihat produk batik yang beredar di Yoyakarta perkembangannya cukup menggembirakan, namun batik khas Yogyakart yang banyak beredar di dominasi motif lama, pembaharuannya belum Nampak secara signifikan, kalaupun ada hanya sebatas mengkomposisikan tata letak beberapa motif yang sudah ada tersebut menjadi satu pola dalam sebuah kain panjang.. Melihat keadaan tersebut maka diperlukan karya-karya ciptaan 
baru yang kreatif dan inovatif yang dapat memperkaya motif batik gaya Yogyakarta.

Berangkat dari kondisi tersebut, penulis ingin mengembangkan motif baru dengan mengambil pohon Keben (Barringtonia Asiatica) sebagai inspirasi motif batik pada kain panjang sekaligus buah Keben sebagai salah satu unsur pewarna alamnya. Ada beberapa alasan yang mendasari penulis mengambil pohon Keben sebagai sumber inspirasi penciptaan, yaitu bentuk bunga dan buah Keben unik dan spesifik sehingga menjadi tantangan dalam pengembangannya. Selain itu pohon Keben memiliki arti yang penting di Keraton Yogyakarta, diungkapkan oleh Sabdacarakatama (2009:140), pohon Keben merupakan salah satu tanaman klangenan Sultan dan hanya ditanam di halaman Kamandhungan utara yang merupakan bagian dari Keraton Yogyakarta. Kawasan Kamandhungan utara juga disebut Keben. Bentuk buah Keben juga sangat penting dalam arsitektur tradisional Jawa yaitu dipakai sebagai hiasan pada rumah tradisional Jawa yang disebut dengan Kebenan yang diukir berbentuk kuncup bunga. Hiasan Kebenan ini juga terdapat pula pada bangunan candi dan juga pada nisan sebagai kepala nisan atau maejan. (Dakung, 1981/1982 : 137) Sekitar tahun 2000 penulis pernah bereksperimen dengan Keben yang memiliki nama latin Barringtonia asiatica untuk pewarnaan alam pada batik, dan hanya buahnya saja yang bisa dipakai untuk pewarnaan alam.

Pada penciptaan ini, penulis akan mestilir bentuk daun, bunga, dan buah Keben menjadi motif baru yang akan dibuat dalam bentuk motif geometrik dan lung-lungan. 4 variasi motif akan diaplikasikan pada kain panjang dengan teknik batik tulis warna alam pada bahan sutra. Pemilihan kain panjang ini berdasarkan fungsi kain panjang yang lebih bervariasi dalam penggunaannya. Dalam fungsinya kain panjang ini bisa juga dipakai sebagai sarung, busana lilitan modern atau sebagai bahan busana potong.

Digunakanannya zat warna alam sebagai upaya mengurangi pencemaran lingkungan akibat penggunaan zat warna sintetis. Warna kain panjang mengarah pada warna khas batik Yogyakarta yaitu Sogan, namun tidak menutup kemungkinan akan diberi sentuhan-sentuhan warna tone yang berbeda.

Menciptakan dan mengembangkan motif batik baru yang memiliki gaya atau corak Yogyakarta merupakan bentuk kepedulian dalam rangka dukungan untuk mempertahankan status Indonesia sebagai Masterpieces of The Oral and Intangible Heritage of Humanity atau sebagai warisan budaya tak benda yang dikukuhkan sejak 2 Oktober 2009 oleh UNESCO. Predikat lain juga diberikan kepada Yogyakarta yang telah ditetapkan sebagai The World Craft City of Batik atau sebagai Kota Batik Dunia pada bulan Oktober 2014 oleh World Craft Center (WCC).

Dari uraian diatas, maka rumusan permasalahannya adalah:

a. Bagaimana menciptaan motif batik baru dengan inspirasi atau sumber ide daun, bunga, dan buah Keben? Warna apa saja yang dihasilkan dari buah Keben?

b. Bagaimana mengaplikasikan zat warna Keben dan motif batik baru tersebut pada kain panjang?

\section{METODE PENCIPTAAN}

Untuk menggambarkan ornamen pada kain yang bertitik tolak dari bentuk riil obyek penciptaan, dilakukan penulis dengan cara stilisasi.(Soedarso, 2006 : 82) Diuraikan oleh Soedarso bahwa stilisasi adalah pengubahan bentuk-bentuk dialam dalam seni untuk disesuaikan dengan suatu bentuk artistik atau gaya tertentu seperti yang banyak terdapat dalam seni hias atau ornamentik. Stilisasi 
dimanfaatkan dalam membuat motif-motif hias yang umumnya diambil dari unsur-unsur alam baik flora maupun fauna. (Soedarso, $2006: 84)$.

\section{Metode Practiced Based Research}

Dalam penciptaan karya ini akan menggunakan metode Practice Based Research, penelitian berbasis praktek merupakan penyelidikan orisinil yang dilakukan guna memperoleh pengetahuan baru melalui praktek dan hasil praktek tersebut. Pada pengertian yang lebih dalam, disebutkan bahwa penelitian berbasis praktek merupakan penelitian yang paling tepat digunakan oleh pencipta karena pengetahuan baru yang didapat dari penelitian yang dilakukan dapat langsung diterapkan pada bidang bersangkutan dan peneliti melakukan yang terbaik dengan menggunakan kemampuan mereka dan pengetahuan yang telah dimiliki pada subyek kajian tersebut. (Malins, Ure, dan Gray:1996,1-2)

Penggunaan metode practised-based research dalam proses penciptaan karya ini untuk proses eksekusinya menggunakan metode action (Lomax, 1996:10) dijelaskan bahwa "....penelitian tindakan adalah jalan untuk mendefinisikan dan mengimplementasikan perkembangan profesional yang relevan dengan bidangnya. Metode practiced based research dan action di atas akan dilengkapi dengan metode penciptaan seni kriya pola tiga tahap enam langkah Gustami, yang mana proses penciptaan karya seni dapat dilakukan melalui metode ilmiah yang direncanakan secara seksama, analitis, dan sistematis. Dalam konteks metodologis terdapat tiga tahap penciptaan karya seni yaitu Eksplorasi, Perancangan, dan Perwujudan. (Gustami: 2007)

\section{Metode Eksperimen dan improvisasi}

Sebagaimana

disinggung dipendahuluan bahwa pohon keben dapat dipakai untuk pewarnaan kain batik. Hal ini sudah diuji coba oleh penulis beberapa tahun yang lalu, tetapi belum terdokumentasi. Penulis juga akan melakukan improvisasi bila pada tahap pelaksanaan menemukan ide ide baru sebagai variasi sepanjang sebagai penunjang karya yang lebih baik.

\section{Metode Pengumpulan data}

Metode pustaka dan metode observasi digunakan untuk mencari data yang berkaitan dengan proses penciptaan, pohon Keben sebagai obyek sumber inspirasi motif dan sumber zat warna alam serta zat warna alam dari tanaman lain sebagai campuran dan kombinasi.

\section{PEMBAHASAN}

\section{a. Proses Penciptaan}

Dari metode pustaka dan observasi dapat diidentifikasikan bagian-bagian pohon Keben yaitu daun, bunga, dan buah yang menjadi sumber acuan penciptaan.

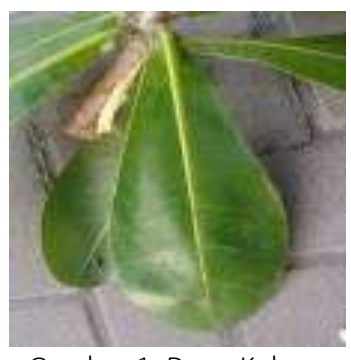

Gambar 1. Daun Keben

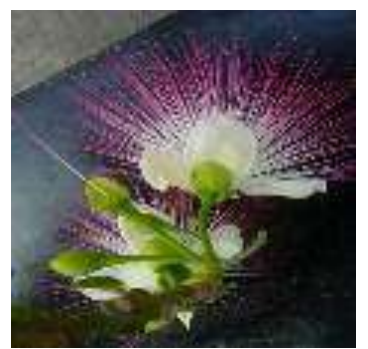

Gambar 2. Bunga Keben

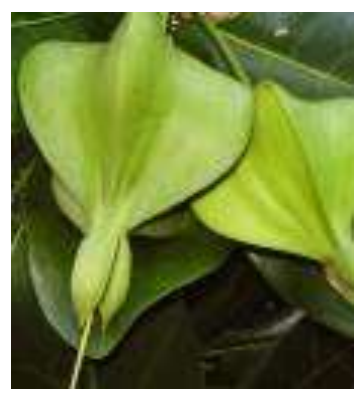

Gambar 3. Buah Keben 


\section{Eksplorasi zat warna Keben}

Pada eksperimen ini buah Keben yang dipakai adalah yang sudah agak tua, yang sudah banyak kandungan pewarnanya. Buah dicacah kecil-kecil dan kemudian direbus dalam 3 wadah stainles steel dalam panci stainless atau email yang Pada saat merebus masing masing ditambah soda abu, soda kue dan cream of tar tar agar zat warna dapat keluar dengan maksimal. Buah Keben direbus lebih kurang selama satu jam. Setelah dingin air rebusan disaring agar bersih dari ampas. Zat warna Keben siap dipakai.

\section{Pengambilan zat warna Kesumba}

Kesumba diambil bijinya, kemudian direbus dengan 3 panci stainlessteel selama 1 jam dan dasing masing ditambah setengah sendok the soda abu, soda kue dan cream of tar tar agar zat warna dapat keluar dengan maksimal. Bila sudah dingin rebusan disaring dan zat warna Kesumba siap digunakan.

\section{Pengambilan Zat Warna Kunyit}

Kunyit merupakan rimpang yang menjadi sumber zat warna alamnya. Sebelum direbus, kunyit dijadikan bubuk dahulu kemudian direbus dalam 3 wadah masing masing ditambah sedikit soda abu, soda kue dan cream of tartar.

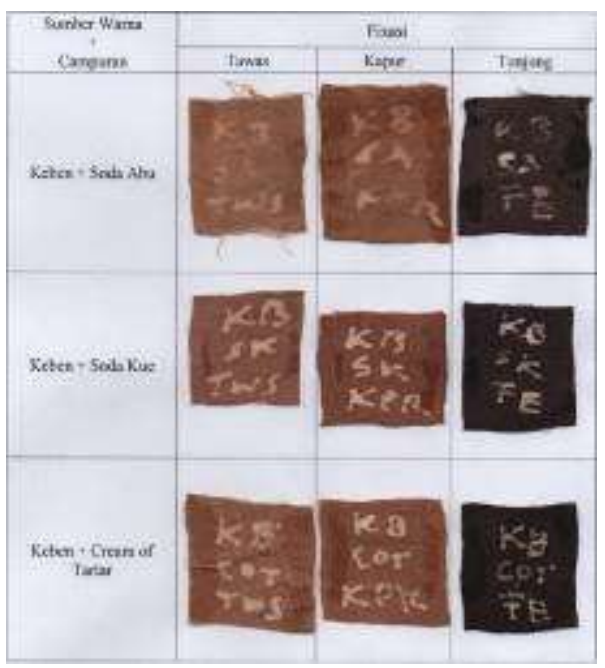

Tabel 1. Arah Warna Keben

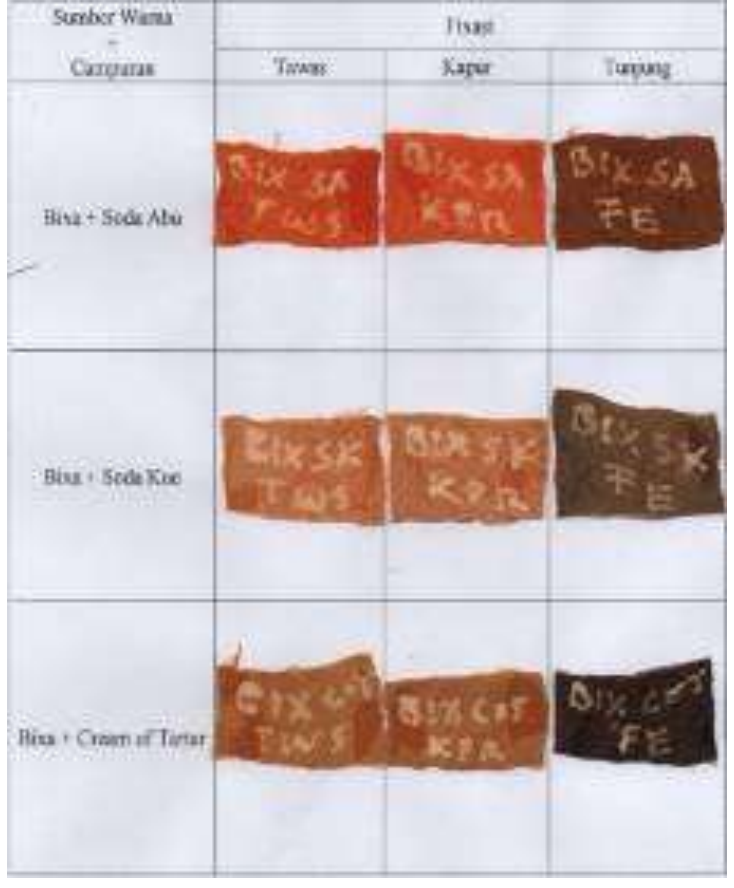

Tabel 2. Arah Warna Kesumba

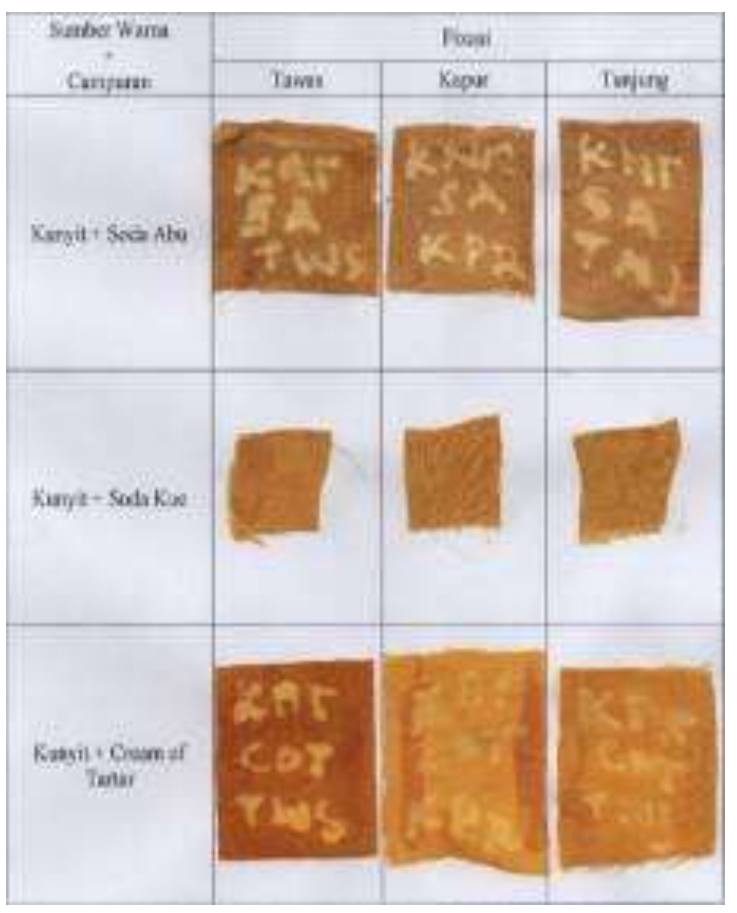

Tabel 3. Arah Warna Kunyit

\section{b. Perwujudan}

Perwujudan merupakan proses memvisalisasikan ide dan konsep dari hasil observasi, eksplorasi dan eksperimentasi yang dituangkan dalam sketsa alternatif baik dari segi bentuk motif, isen isen, komposisi dan arah warna. 


\section{Desain}

Tahap ini meliputi pembuatan sket alternatif motif Keben dan sket alternatif pola. Langkah pertama membuat sket daun, bunga, dan buah. Hasil sket awal ini menjadi pijakan pengembangan bentuk motif yang digubah, dikembangkan dan digayakan sesuai kemampuan dan rasa estetika penulis menjadi motif batik utama yang nantinya akan disusun dan dikomposisikan menjadi pola batik baru kain panjang. 4 desain terpilih akan divisualisasikan yaitu pola ceplok, parang dan pola bebas lung lungan. Adapun sket-sket motif batik tersebut sebagai berikut.
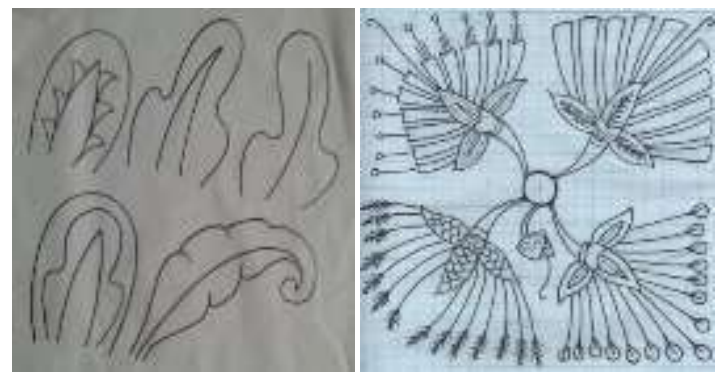

Gambar 4. Sket Daun

Gambar 5. Sket Bunga

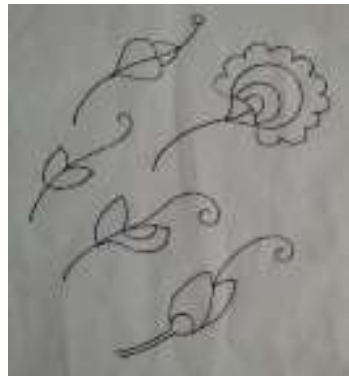

Gambar 6. Sket Daun

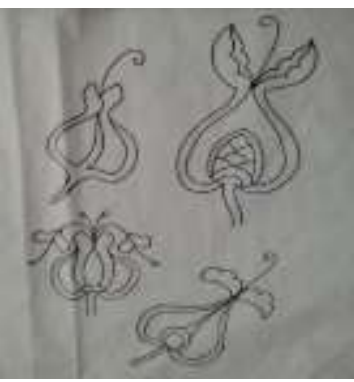

Gambar 7. Sket Buah

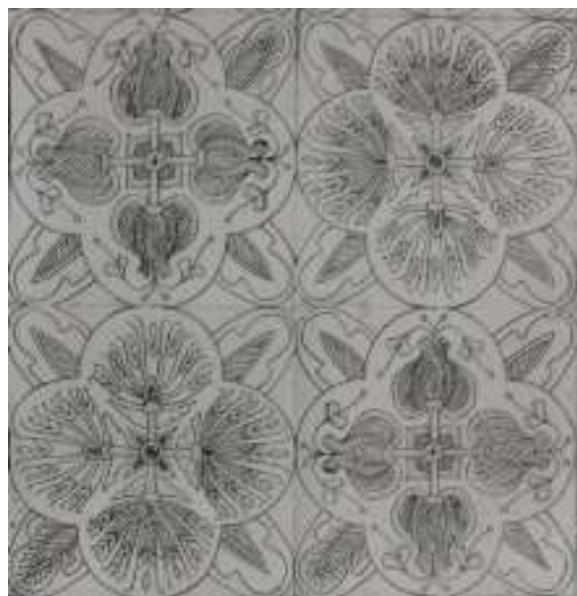

Gambar 8. Desain Ceplok Kotak Keben

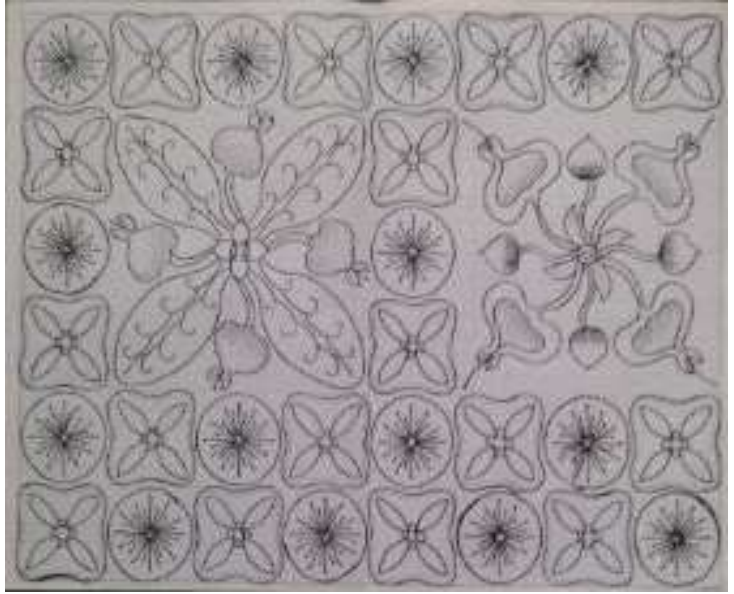

Gambar 9. Desain Ceplok Sekar Keben

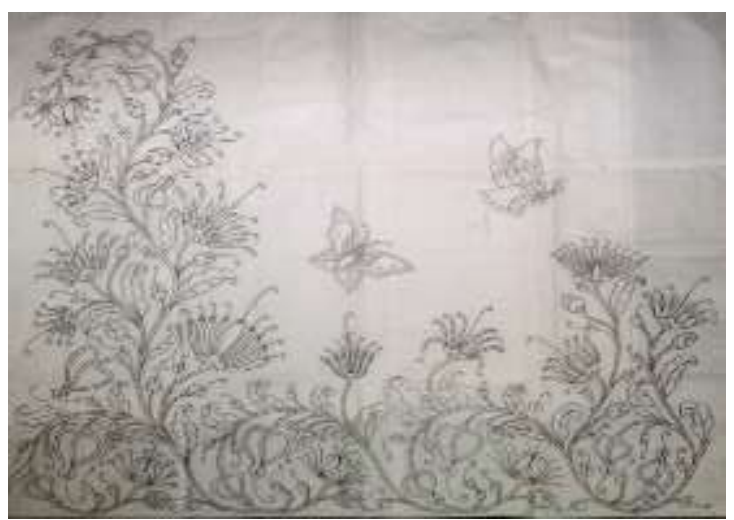

Gambar 10. Desain Parang Barringtonia Asiatica

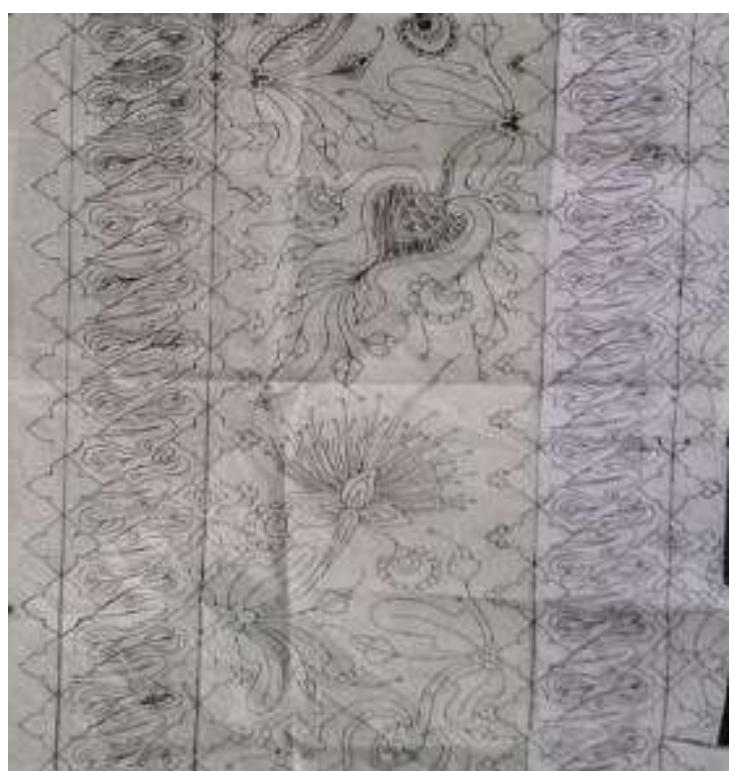

Gambar 11. Desain Lung Putri Keben 


\section{c. Proses Pembatikan}

\section{Pemindahan motif pada kain sutera (nyorek)}

Empat desain terpilih kemudian dipindah di kain sutera dengan cara dijiplak menggunakan pensil 4b.

\section{Pencantingan (pembatikan)}

Selesai pemindahan motif, kemudian semua kain dibatik (dicanting) sesuai dengan gambar, pencantingan berupa klowong, tembok dan isen-isen.

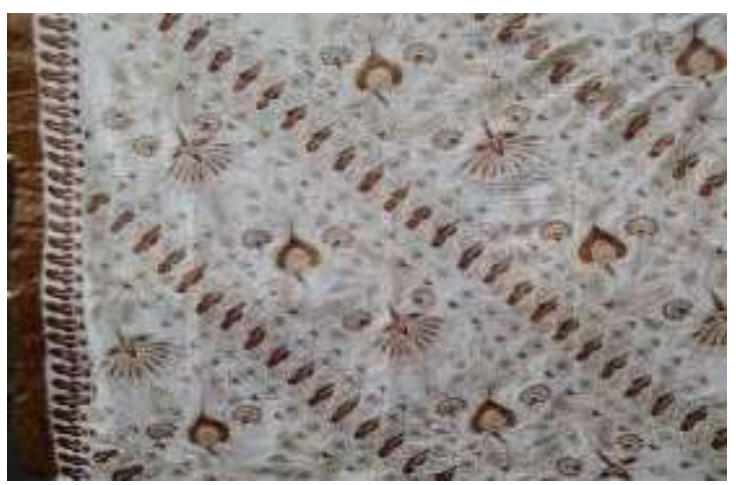

Gambar 12. Batikan Parang Barringtonia Asiatica

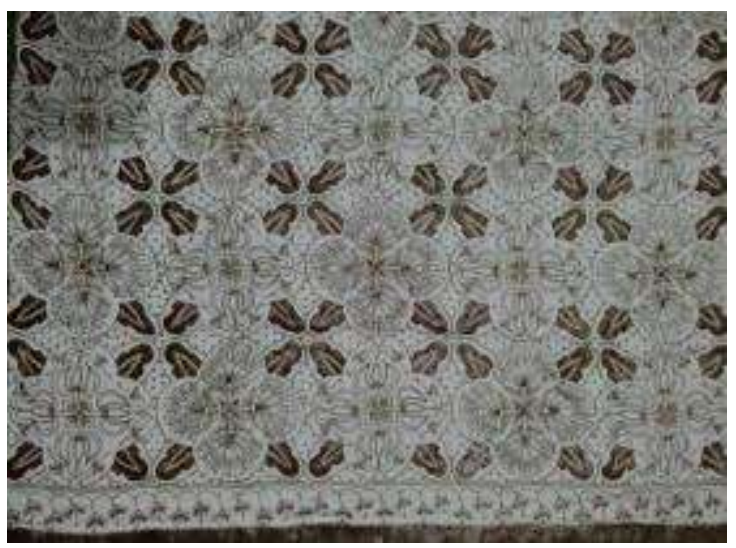

Gambar 13. Batikan Ceplok Sekar Keben

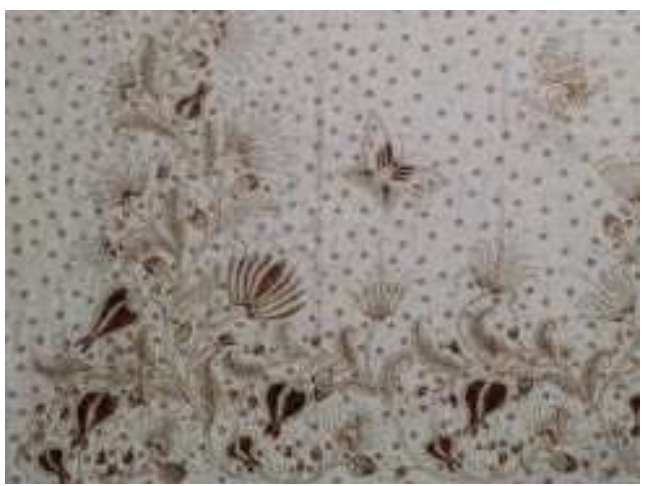

Gambar 14. Batikan Lung Putri Keben

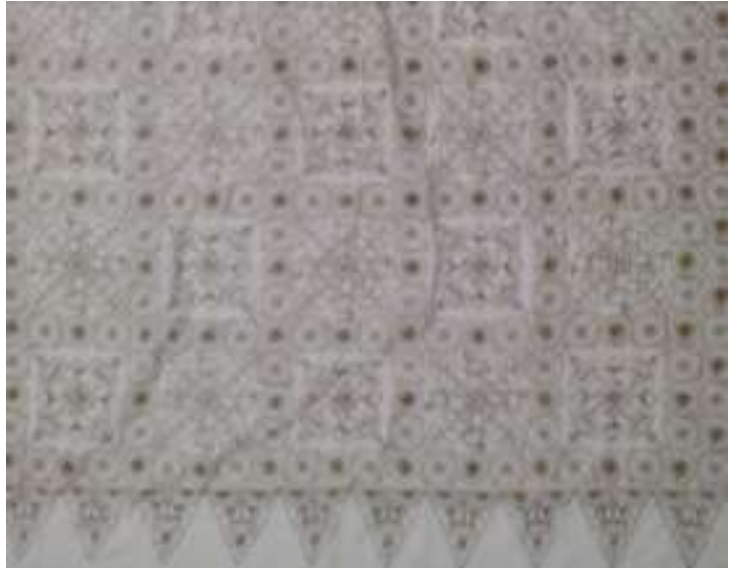

Gambar 15. Batikan Ceplok Kotak Keben

\section{Proses pencelupan zat warna keben}

Zat warna alam keben disiapkan dalam bak celup. Batikan yang sudah dibasahi larutan air dan TRO direndam dalam pewarna sekitar 15 menit, kemudian ditiriskan dan dianginanginkan. Setelah kering direndam lagi dalam pewarna, demikian dilakukan berkali kali paling sedikit 6 kali. Setelah kering, kain di fiksasi dengan cara direndam 10-15 menit dalam larutan tawas untuk warna kuning, kapur untuk warna coklat dan tunjung untuk warna hitam.

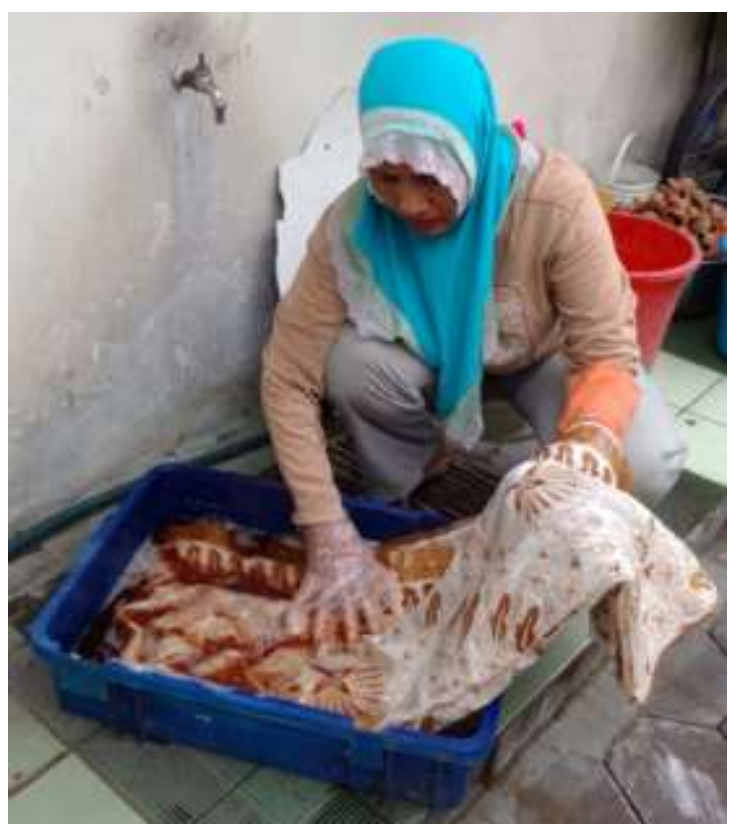

Gambar 16. Pencelupan pewarna keben 


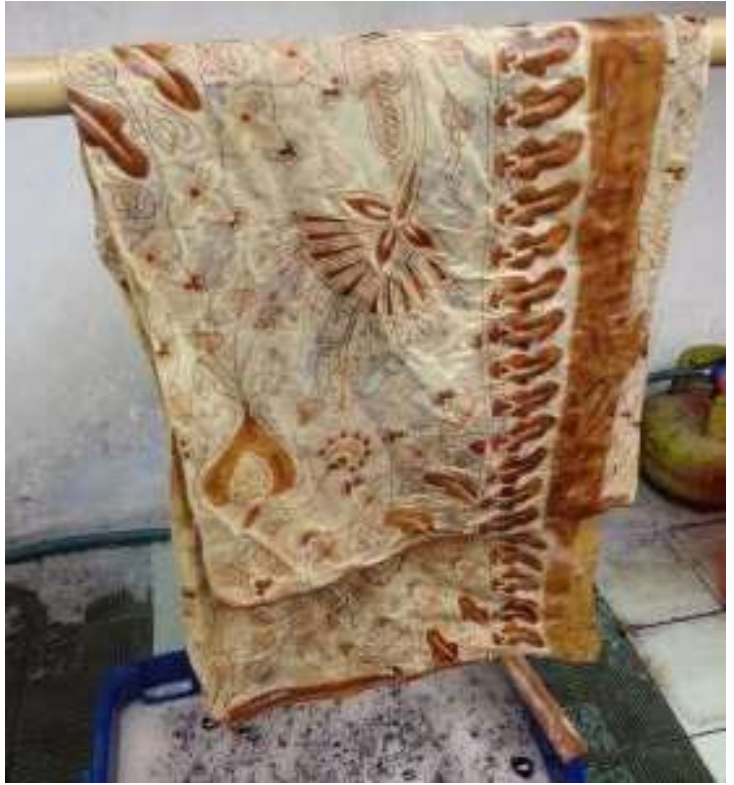

Gambar 17. Kain ditiriskan

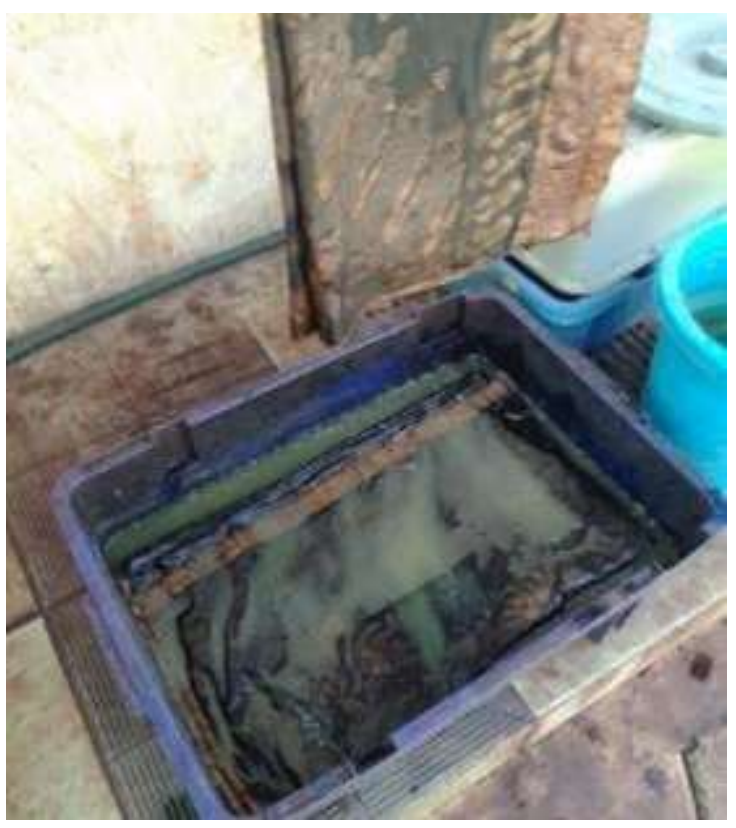

Gambar 18. Proses Fiksasi

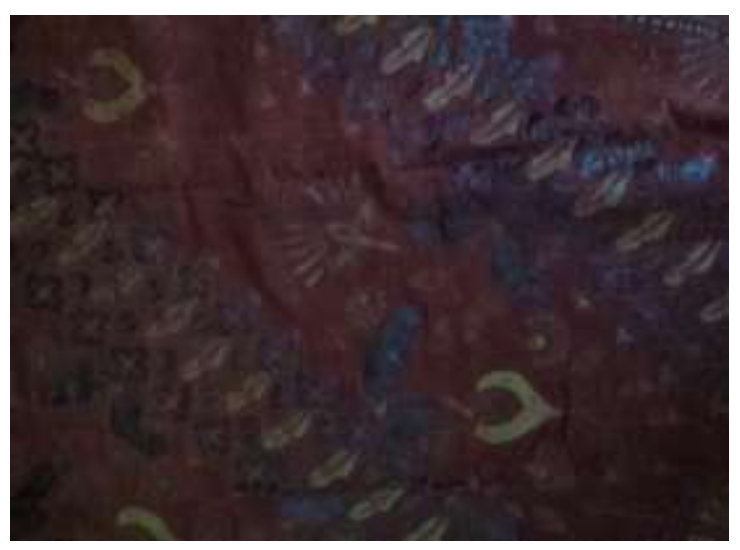

Gambar 19. Warna Kain Hasil Fiksasi

\section{Pencelupan zat warna biru Indigofera}

Proses pewarnaan indigofera belalui fermentasi. Sebagai konduktor digunakan gula kelapa atau gula aren. Perbandingan ukuran zat warna indigofera pasta indigofera : Gula Aren : kapur injet : air $=1: 1: 0,2: 8$. Langkah selanjutnya adalah mencampur semua bahan tersebut sampai rata dan larutan didiamkan selama 10 jam agar terjadi fermentasi. Setelah 10 jam adonan diaduk dan diperhatikan bila muncul warna hijau kekuningan maka campuran warna behasil dan siap digunakan.

Cara mencelupnya adalah kain batikan direndam sebentar di air larutan TRO dan ditiriskan, kemudian direndam dalam larutan indigofera selama 20-30 menit, setelah itu diangkat dan diangin-anginkan hingga kering untuk kemudian direndam lagi dalam larutan dan di keringkan. Demikian dilakukan berkali kali hingga mencapai warna yang diinginkan.

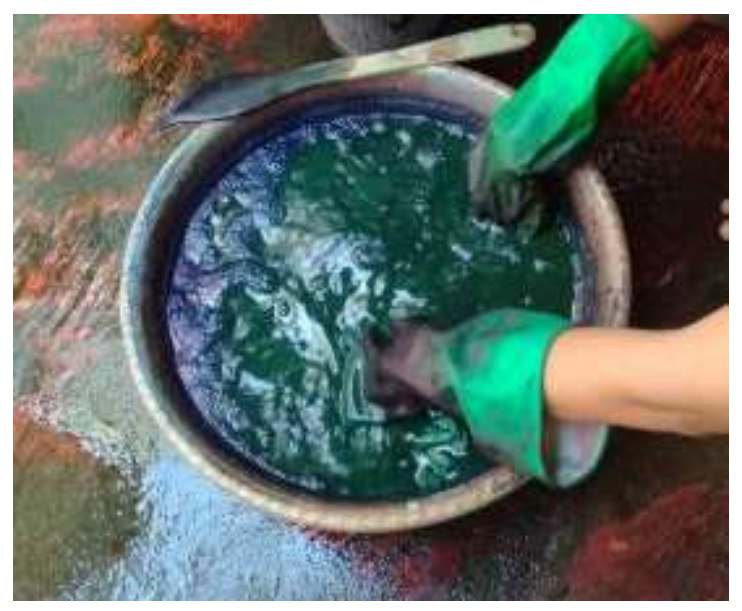

Gambar 20. Zat warna Indigofera siap digunakan

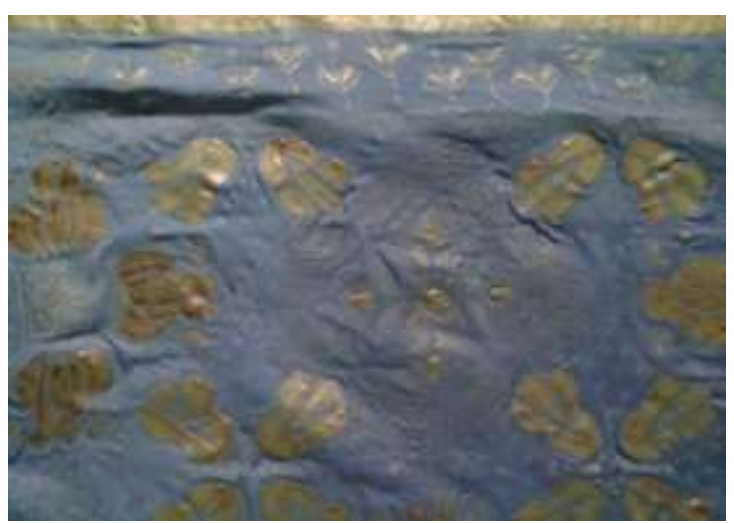

Gambar 21. Hasil 6 kali celupan indigofera 


\section{Pelorodan}

Pada tahap ini merupakan tahap terakhir dari rangkaian tahapan dalam proses batik, yaitu melepas malam dari kain. Caranya adalah dengan mendidihkan 10 liter air dalam panci email besar yang ditambah 1ons soda abu dan 1ons tepung kanji yang sudah dilarutkan dengan air. Dalam keadaan air mendidih kain dimasukkan dan direbus sampai malam lepas, kemudian diangkat dan dicuci air bersih. Bila belum bersih, diulang sampai malam bersih tidak ada yang menempel pada kain.

\section{Hasil Karya}

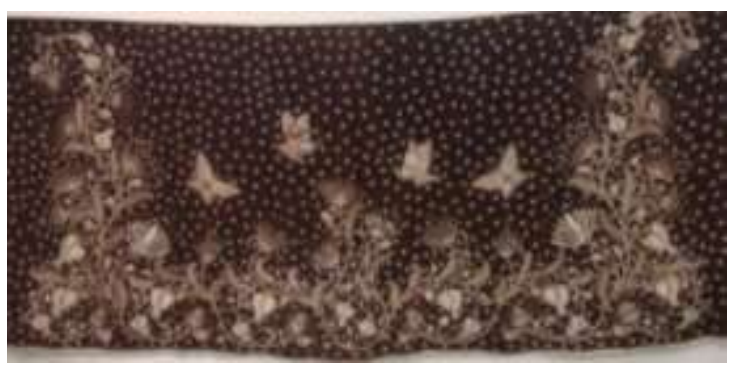

Gambar 22. Pola Lung Putri Keben

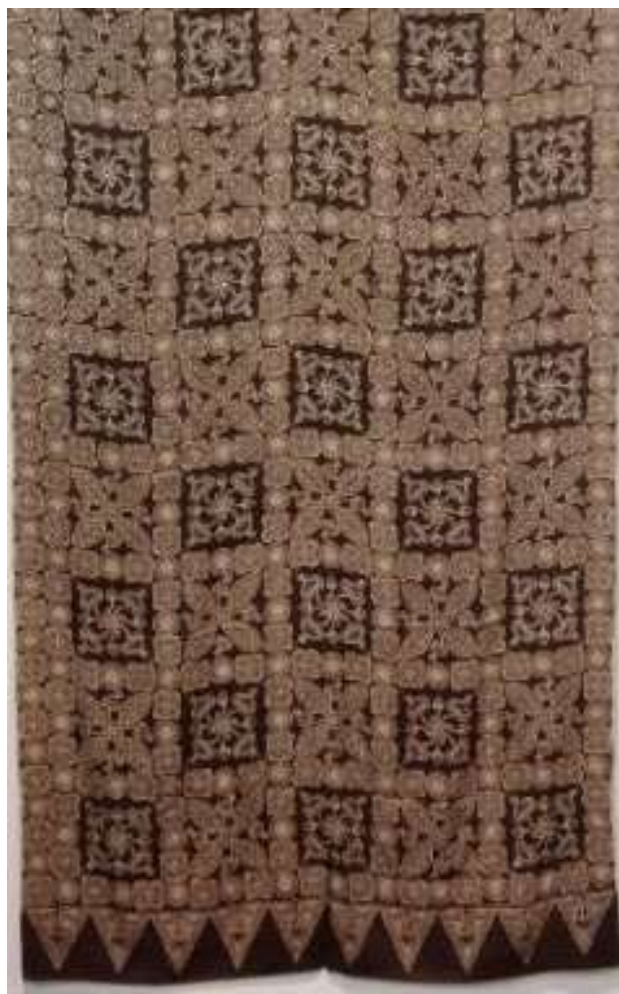

Gambar 23. Pola Ceplok Kotak Keben

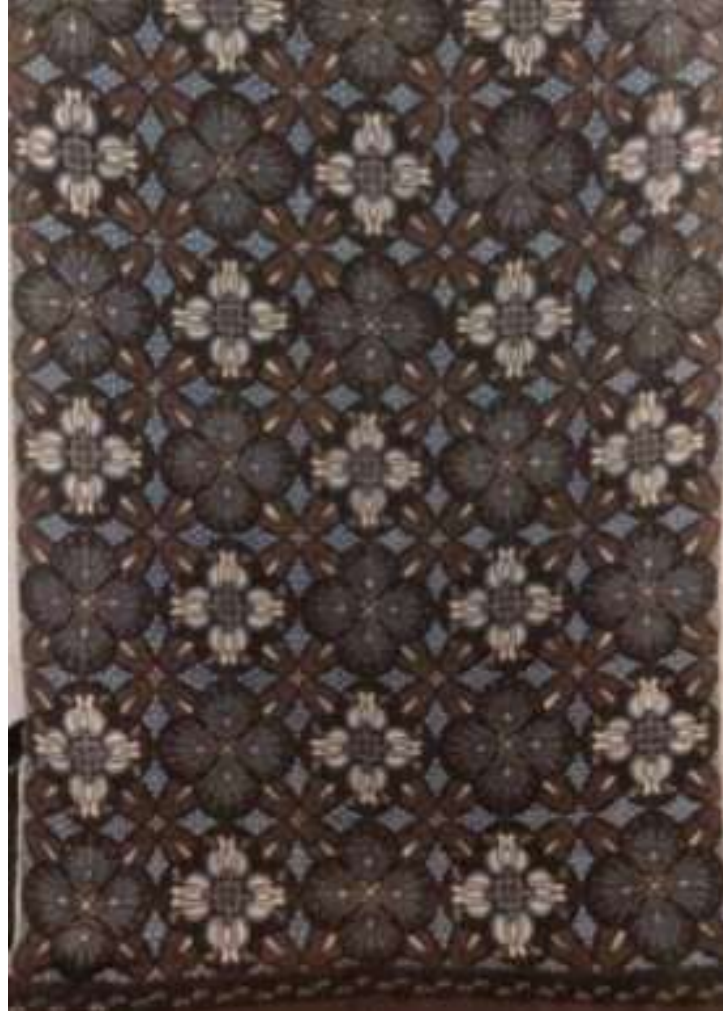

Gambar 24. Pola Ceplok Sekar Keben

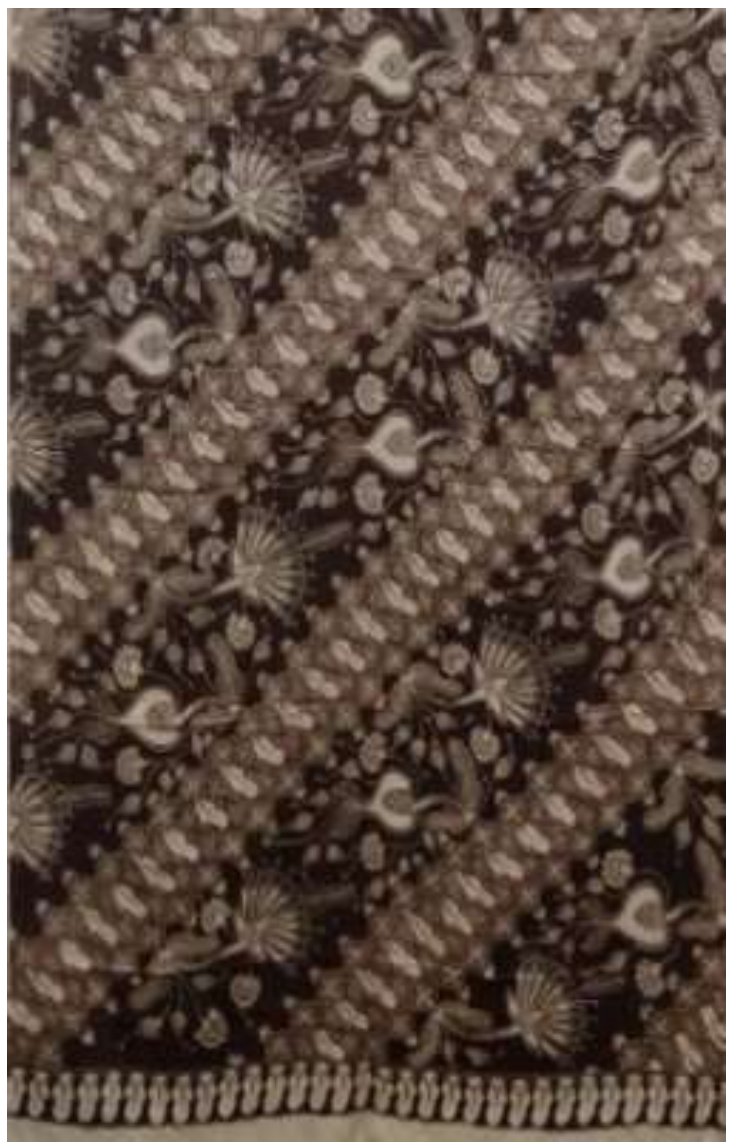

Gambar 25. Pola Parang Barringtonia Asiatica 


\section{PENUTUP}

Alam termasuk didalamnya tumbuhtumbuhan dapat menjadi sumber inspirasi penciptaan karya seni Batik, sebagaimana pada kesempatan ini penulis mengambil pohon Keben sebagai inspirasi penciptaan Batik Kain Panjang dengan salah satu pewarna alamnya adalah buah Keben itu sendiri.

Perancangan meliputi bentuk daun, bunga dan buah yang unik memberikan visualisasi yang menarik. Bentuk bunga, buah dan daun tidak digambar secara realis, tetapi digayakan dan digubah kedalam bentukbentuk yang penggambarannya sudah distilisasi. Daun, bunga dan buah distilir dalam berbagai alternatif unsur unsur motif khas batik dan diberi isen isen yang menjadi ruhnya batik. Unsur unsur motif inilah yang diatur, dikomposisikan dan diorganisasikan menjadi pola batik pada kain panjang yang dapat dipakai dalam beberapa fungsi. Selain sebagai kain panjang dalam busana tradisional juga dapat digunakan sebagai busana lilitan modern dan dapat pula sebagai bahan busana modern atau fashion.

Melalui eksperimen, didapatkan warna yang menurut penulis cukup memberi variasi dan tone warna yang menakjubkan, tidak terduga, dan sulit untuk mendapatkan hasil warna dengan tone yang sama meskipun dari bahan warna dan proses yang sama. Penggunaan pewarna alami jauh berbeda dengan penggunaan pewarna kimia. Pewarna alami untuk batik membutuhkan jangka waktu yang lama, mulai dari persiapan bahan kain dasar, persiapan bahan warna sampai pengolahan pengambilan kandungan warna hingga pencelupan warnanya paling sedikit enam kali celup. Proses batik menggunakan zat warna alam tidak bisa tergesa gesa, diperlukan kesabaran agar warna yang melekat pada kain dapat maksimal.

4 lembar kain panjang berhasil diwujudkan dengan warna khas Yogyakarta yaitu warna Sogan. Dalam perwujudannya penggunaan zat warna alam berbeda-beda campurannya, hal ini dilakukan untuk mendapatkan tone warna yang berbeda. 1 lembar kain motif Ceplok Sekar Keben diwujudkan dengan kombinasi zat warna indigofera yang berwarna biru wedel dengan kombinasi campuran zat warna alam keben, tingi, dan jambal. 1 lembar kain motif Ceplok Kotak Keben diwujudkan dengan menggunakan pewarna alam keben untuk mendapatkan warna coklat pada motif ceplok dan coklat tua pada latarnya. 1 lembar kain motif Parang Barringtonia Asiatica diwujudkan menggunakan kombinasi campuran zat warna keben, kunyit, tegeran, tingi dan jambal. 1 lembar kain motif Lung Putri Keben diwujudkan dengan menggunakan kombinasi zat warna kesumba, kunyit, tingi, dan jambal.

\section{DAFTAR PUSTAKA}

Gustami Sp., Butir-Butir Mutiara Estetika Timur: Ide Dasar Penciptaan Seni Kriya Indonesia, Prasista, Yogyakarta, 2007.

J.E. Jasper dan Mas Pirngadie, De Batik-kunst : De Inlandsche Kunstnijverheid in Nederlandsch Indie Vol.3, The Hague, Mouton \& Co, 1916.

Malins, J., Ure, J. Dan Gray, C., The Gap: Addressing Practised-Based Research Training Requirements for Designers, The Robert Gordon University, Aberden, UK.

Mari S. Condronegoro, Busana Adat 18771937 Kraton Yogyakarta: Makna dan Fungsi Dalam Berbagai Upacara, Yayasan Pustaka Nusatama, Yogyakarta, 2010.

Sabdacarakatama, Sejarah Keraton Yogyakarta, Narasi, Yogyakarta, 2009.

Sewan Susanto, Seni Kerajinan Batik Indonesia, Yogyakarta, Balai Penelitian Batik dan Kerajinan Departemen Perindustrian, 1973 
Sp., Soedarso, Tinjauan Seni Sebuah Pengantar untuk Apresiasi Seni, Saku Dayar Sana, Yogyakarta, 1990.

Trilogi Seni : Penciptaan Eksistensi dan Kegunaan Seni, Badan Penerbit ISI Yogyakarta, 2006, 82.

Sugiarto Dakung, Arsitektur Tradisional Daerah Istimewa Yogyakarta,Departemen Pendidikan dan Kebudayaan Proyek Inventarisasi dan Dokumentasi Kebudayaan Daerah, 1981/1982.

Suyanto, A.N., Sejarah Batik Yogyakarta,Rumah Penerbitan Merapi kerjasama dengan Yayasan Adi Karya IKAPI Ford Foundation, 2002. 